\title{
Physical and Mechanical Properties of Particleboard Produced from Some Timber Trees Irrigated with Treated Wastewater
}

\author{
Khaled T. S. Hassan*, Ibrahim E. A. Kherallah, Ahmed A. A. Settway, and Heba M. Abdallah ${ }^{1}$
}

\begin{abstract}
This study aimed to manufacture particleboards from Casuarina cunninghamiana (C), Eucalyptus camaldulensis (E), and Pinus halepensis (P) trees irrigated with treated wastewater and their mixtures (E-C, E-P, and C-P) with 50\%:50\% for each individual raw material. Two urea formaldehyde resin levels $(9 \%$ and $13 \%)$ were used. Modulus of rupture (MOR), modulus of elasticity (MOE), and internal bond strength (IB) as mechanical properties and physical properties (water absorption and thickness swelling) were determined. The C-P panels with $9 \%$ and $13 \%$ resin levels showed the best mechanical and water resistant performance. All the $13 \%$ panels satisfy the minimum requirement of the European standard for the MOE, MOR, and IB except for the MOE of (P) panels, which was very close to the recommended value. The mixtures improved the water absorption and thickness swelling compared with the other produced panels especially for the $13 \%$ resin content panels. The (E-C) with $9 \%$ resin content showed the lowest mechanical properties and water resistance values. The three furnish types and their mixtures showed its suitability for particleboard production using the board processing conditions specified in this study.
\end{abstract}

Keywords: Modulus of elasticity, Treated wastewater, Internal bond strength, Water absorption.

\section{INTRODUCTION}

Egypt imports a large quantity of particleboard and oriented strand board (OSB). In 2018, the imported quantity of particleboard reached $47961 \mathrm{~m}^{3}$ versus $18016 \mathrm{~m}^{3}$ for production (FAO, 2020). This of course is due to the growing demands for wood-based panels. In general, the major problem that faces the particleboard production in Egypt is the lack of raw materials. Usually, low-density wood species are preferred in the particleboard industry where it provides high strength products due to the high compaction ratio ( $\mathrm{Xu}$ et al., 2004).

The commercial production of the particleboard in Egypt is based on Eucalyptus and Casuarina wood species, in addition to some agricultural residues such as, flax shives and bagasse fragments. The genus Eucalyptus is native to Australia, this genus contains

DOI: 10.21608 /asejaiqjsae.2020.77058

${ }^{1}$ Alexandria University, Faculty of Agriculture, Department of Forestry and Wood Technology, Alexandria, Egypt.

* Corresponding author. E-mail address: khaledtaha85@gmail.com

Received February 9, 2020, Accepted March 10, 2020 over 700 species (Doughty, 2000 and Hudson et al., 2015). According to (Coppen, 2003), the genus of Eucalyptus is a fast-growing tree; several tree species of this genus can be utilized effectively for lumber production and paper production.

In Egypt, Casuarina species are utilized for windbreaks and shelterbelts and its wood can be utilized for pulp and paper production (Kandeel et al., 1982). Aleppo pine (Pinus halepensis Mill.) is indigenous to the countries around the Mediterranean Sea (Gindel, 1944) and this species has the ability to withstand drought stress (Cortina et al., 2011). Several adhesives can be used for particleboard production such as urea formaldehyde, melamine formaldehyde, and melamine urea formaldehyde. From these, urea formaldehyde adhesive is the most common resin type that it is widely used around the world due to the low production costs (Ansell, 2015; Wang et al., 2018). It is worth mentioning that the particleboard industry is highly dependent on urea formaldehyde adhesives (Dinwoodie, 1978). In order to examine the quality of the produced particleboards some properties need to be determined, such as physical (density, water absorption and thickness swelling), mechanical (static bending properties (MOE and MOR) and internal bond strength), and chemical (volatile organic compounds and formaldehyde emissions) (Ansell, 2015).

Recently, there is a tendency to reuse treated wastewater efficiently instead of polluting the environment through its disposal. In Egypt, the awareness about reusing wastewater has been increased significantly during the last two decades through planting man-made forests with various tree species irrigated with treated wastewater.

In general, the major problem that faces the particleboard production in Egypt is the lack of the raw materials. The commercial production of the particleboard in Egypt is based on Eucalyptus and Casuarina wood species, in addition to some agricultural residues such as, flax shives and bagasse fragments. Regarding the shortage of raw materials used in particleboard production in Egypt, the fast growing tree 
species that irrigated with treated wastewater can play a major role in providing raw materials for the production of wood composites.

Lack of information on the performance of the particleboard produced using these raw materials with different production parameters limits the expansion in the commercial production of these panels with various characteristics. Therefore, this research aimed to investigate the feasibility of producing particleboards using three tree species irrigated with treated wastewater (Eucalyptus camaldulensis Dehn., Casuarina cunninghamiana Miq., and Pinus halepensis Mill.). In addition, the mechanical behavior (modulus of elasticity, modulus of rupture, and internal bond strength) and physical properties (water absorption and thickness swelling) were evaluated.

\section{MATERIALS AND METHODS}

In this study, three tree genera (Casuarina cunninghamiana, Eucalyptus camaldulensis and Pinus halepensis) were chosen randomly from the Egyptian / Chinese Friendship Forest, Sadat City, Monoufia Governorate, Egypt. The trees were irrigated with treated wastewater and the age ranged from 15 to 16 years old.

The density of raw materials was determined based on oven-dried mass and green volume. The extractives content of wood were determined according to the (ASTM D1105 - 96, 2000).

Six kinds of single-layer particleboards were produced: (1) panels with $100 \%$ E. camaldulensis wood particles denoted as (E), (2) panels with $100 \% C$. cunninghamiana denoted as (C), (3) panels with $100 \%$ $P$. halepensis wood particles denoted as (P), (4) panels with $50 \% \quad E$. camaldulensis and $\% 50 \% \quad C$. cunninghamiana denoted as (E-C), (5) panels with 50\% E. camaldulensis and $\% 50 \%$ P. halepensis denoted as (E-P), and (6) panels with 50\% C. cunninghamiana and $50 \%$ P. halepensis denoted as (C-P).

The particles size used for all board types was 20-40 mesh. Urea formaldehyde (50\% solid content) was used as a binder with two levels (9\% and 13\%) and 2\% ammonium chloride (30\% solid content) were added based on the oven-dried weight of particles. The target density of all the manufactured panels was $680 \mathrm{~kg} / \mathrm{m}^{3}$ (corresponded to $10 \mathrm{~mm}$ thickness of finished boards). The pressure conditions were $2.5 \mathrm{~N} / \mathrm{mm}^{2}$ pressure and $160{ }^{\circ} \mathrm{C}$ for hot pressing temperature for 5 min pressing time.

In order to evaluate the quality of the produced panels, mechanical and physical tests were conducted. The mechanical performance of the produced panels was modulus of elasticity (MOE) modulus of rupture
(MOR) according to the European standard (EN 310, 1993), and internal bond strength (IB) according to (EN $319,1993)$. The physical tests were water absorption and thickness swelling after $2 \mathrm{~h}$ and $24 \mathrm{~h}$ water immersion (EN 317, 1993)

The experimental design used for the present study was complete randomized design (CRD). All data were subjected to analysis of variance tests (ANOVA test at 95\% confidence level) to determine the differences among the determined characteristics. In addition, Fisher's LSD method was used to compare all possible pairs of means.

\section{RESULTS AND DISCUSSION}

The basic density values of the three raw materials used for the particleboard manufacturing in this study were presented in (Figure 1). The mean values were found to be $0.58,0.53$, and $0.46 \mathrm{~kg} / \mathrm{m}^{3}$ for $E$. camaldulensis, C. cunninghamiana, and P. halepensis, respectively. The mean comparisons using the Fisher's LSD method showed that the three density values were significantly different at $95 \%$ probability level.

The mean values of total extractive content for the three raw materials are presented in (Figure 2). The values were found to be $9.26 \%, 4.32 \%$, and $3.16 \%$ for E. camaldulensis, $C$. cunninghamiana, and $P$. halepensis respectively; it is clear that E. camaldulensis had the highest value. The Fisher's LSD test showed that the three density values were significantly different at $95 \%$ confidence level.

The mean values of the modulus of rupture (MOR), modulus of elasticity (MOE), and internal bond strength (IB) for the produced panels are presented in (Table 1).

The analysis of variance (ANOVA) for all the mechanical properties tested in this study revealed that there were significant differences for the resin levels, furnish type and the interaction between resin levels and furnish type at $95 \%$ confidence level. Fisher's LSD test was applied to compare the differences among the means of resin levels and furnish types (Table 1). The European standard (EN 312, 2005) recommends a minimum MOR value of $12.5 \mathrm{~N} / \mathrm{mm}^{2}$ for the particleboards manufactured for general-purpose use in dry conditions. All particleboards produced with $9 \%$ and $13 \%$ UF glue level satisfied the minimum requirement indicated by the European standard except the $(\mathrm{P})$ and $(\mathrm{E}-\mathrm{C})$ panels with $9 \%$ resin content.

Upon the obtained results, the (C-P) panels with 13 $\%$ urea formaldehyde (UF) resin content gave the highest MOR values compared to the other produced panels. The lowest MOR values were observed in (E-C) panels with $9 \%$ resin content. 


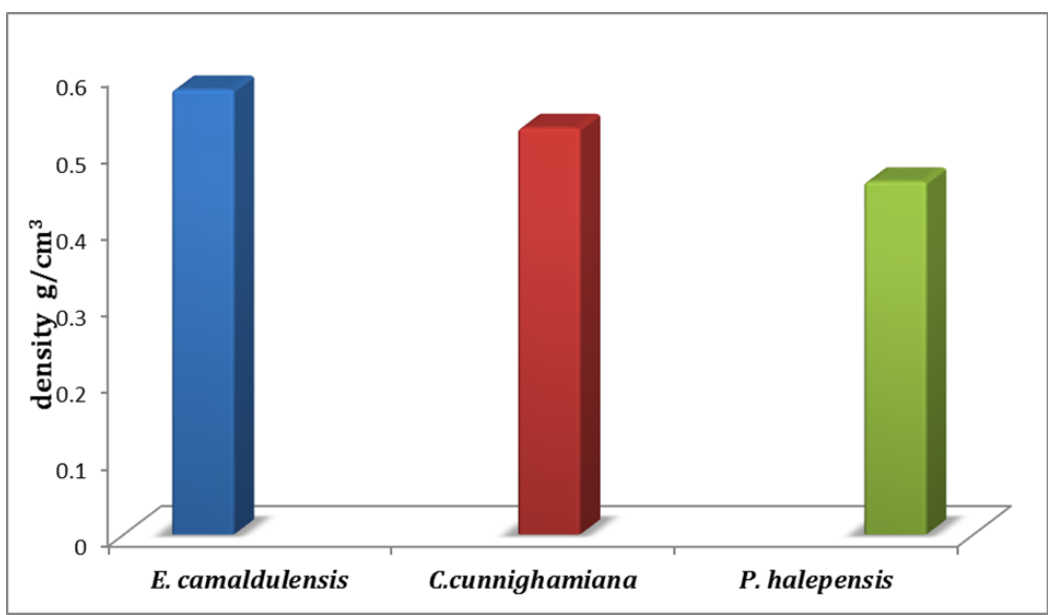

Fig. 1. The average values of density for the three wood species.

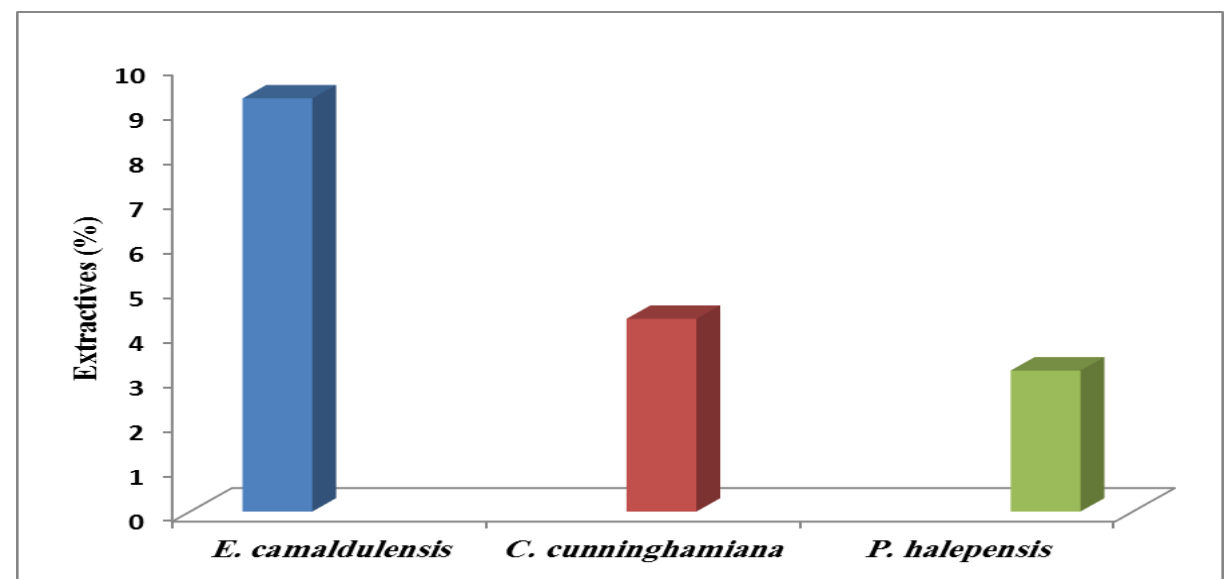

Fig. 2. The average values of total extractives content for the three wood species.

Table 1. Mean values of modulus of rupture (MOR), modulus of elasticity (MOE), and internal bond strength (IB) of the produced particleboards.

\begin{tabular}{lcccccc}
\hline & \multicolumn{2}{c}{ MOR } & \multicolumn{2}{c}{ MOE } & \multicolumn{2}{c}{ IB } \\
\cline { 2 - 7 } Items & \multicolumn{2}{c}{ UF resin content (\%) } & \multicolumn{2}{c}{ UF resin content (\%) } & \multicolumn{2}{c}{ UF resin content (\%) } \\
\cline { 2 - 7 } C. cunninghamiana $(\mathrm{C})$ & $\mathbf{9 \%}$ & $\mathbf{1 3 \%}$ & $\mathbf{9 \%}$ & $\mathbf{1 3 \%}$ & $\mathbf{9 \%}$ & $\mathbf{1 3 \%}$ \\
& $13.56^{\mathrm{ab}}$ & $18.02^{\mathrm{bc}}$ & $1376.3^{\mathrm{ab}}$ & $2123.8^{\mathrm{b}}$ & $0.94^{\mathrm{a}}$ & $1.34^{\mathrm{a}}$ \\
E. camaldulinsis (E) & $(1.1)$ & $(1.74)$ & $(99.8)$ & $(80.32)$ & $(0.11)$ & $(0.11)$ \\
& $12.9^{\mathrm{ab}}$ & $19.38^{\mathrm{abc}}$ & $1493.4^{\mathrm{a}}$ & $2151.9^{\mathrm{ab}}$ & $0.99^{\mathrm{a}}$ & $1.37^{\mathrm{a}}$ \\
P. halepensis (P) & $(0.71)$ & $(0.86)$ & $(94.4)$ & $(116.5)$ & $(0.09)$ & $(0.05)$ \\
& $10.63^{\mathrm{cd}}$ & $17.29^{\mathrm{c}}$ & $1281.9^{\mathrm{b}}$ & $1725.6^{\mathrm{c}}$ & $0.68^{\mathrm{b}}$ & $1.06^{\mathrm{b}}$ \\
E-C & $(0.47)$ & $(1.73)$ & $(59)$ & $(66.67)$ & $(0.12)$ & $(0.05)$ \\
& $9.46^{\mathrm{d}}$ & $20.35^{\mathrm{ab}}$ & $842.4^{\mathrm{c}}$ & $2221.4^{\mathrm{ab}}$ & $0.45^{\mathrm{c}}$ & $1.40^{\mathrm{a}}$ \\
E-P & $(0.71)$ & $(1.76)$ & $(83.3)$ & $(77.98)$ & $(0.12)$ & $(0.1)$ \\
& $12.14^{\mathrm{bc}}$ & $17.35^{\mathrm{c}}$ & $1332.1^{\mathrm{b}}$ & $1830.4^{\mathrm{c}}$ & $0.93^{\mathrm{a}}$ & $1.31^{\mathrm{a}}$ \\
C-P & $(1.45)$ & $(0.56)$ & $(150.1)$ & $(63.71)$ & $(0.07)$ & $(0.2)$ \\
& $14.23^{\mathrm{a}}$ & $20.44^{\mathrm{a}}$ & $1399.1^{\mathrm{ab}}$ & $2282.5^{\mathrm{a}}$ & $1.07^{\mathrm{a}}$ & $1.45^{\mathrm{a}}$ \\
& $(1.11)$ & $(0.72)$ & $(91.2)$ & $(36.11)$ & $(0.06)$ & $(0.09)$ \\
\hline
\end{tabular}

* Values in $\mathrm{N} / \mathrm{mm}^{2}$; Means in the same column which do not share a common letter are significantly different at $95 \%$ confidence level. 
There were no significant differences between (C) and (E) particleboards in this study. Moreover, the MOR values for the mixtures except for the (E-C) panels with 9\% resin level showed the ability to produce panels with acceptable ultimate breaking strength.

For modulus of elasticity (MOE), the (C-P) panels with $13 \%$ UF resin content showed the highest value compared with the other produced panels. The lowest MOE value was observed in (E-C) panels with $9 \%$ resin content. The European specifications (EN 312, 2005) recommends a minimum MOE value of $1800 \mathrm{~N} / \mathrm{mm}^{2}$ for particleboards for interior fitments (including furniture) for use in dry conditions. According to this study, all particleboards produced using $13 \%$ UF glue satisfied the minimum conditions required by standards except for $(\mathrm{P})$ panels which was very close to this value. On the other hand, almost particleboards produced with $9 \%$ UF resin level does not satisfy the minimum requirement of the (EN 312, 2005). Generally, the boards having lower mechanical properties tested in this study can be used as insulating material in buildings, because such materials would not be subjected to any mechanical load.

The (C-P) panels with $13 \%$ UF resin content gave the highest value for the internal bond strength (IB) in comparison with the other produced panels. The lowest IB value was observed in (E-C) panels with $9 \%$ resin content. The (IB) strength of the (E) and (C) panels were better than those (P) panels. Generally, the (IB) strength increased with the increase in the level of urea formaldehyde resin. The European standard (EN 312, 2005) recommends a minimum (IB) value of 0.28 $\mathrm{N} / \mathrm{mm}^{2}$ for the particleboards manufactured for generalpurpose use in dry conditions. Thus, all particleboards produced with $13 \%$ and 9\% UF resin achieved the minimum values recommended by the (EN 312, 2005) standard.

Extractives may play an important role in the properties of the panels especially the mixtures. According to (Foster, 1967), cold and hot water extractives, such as acetic and uronic acids, destroy the bond between the wood and resin during hot pressing. They decrease the $\mathrm{pH}$ of wood and cause early UF resin setting.

The obtained results were in agreement with (Zheng et al. (2006); Pan et al. (2007); Hassan, (2009)) since they found that with increasing UF resin levels the values of MOE and MOR of the panels were increased. Ashori and Nourbakhsh (2008), reported that the resin level was the main parameter affecting the static bending properties (MOE and MOR) and the (IB). In addition, Pan et al. (2007) and Saad and Kamal, (2012) concluded that boards with higher resin contents had higher MOR, MOE, and IB values. In contrast to the majority of studies, Ayrilmis et al. (2012) investigated the effect of resin content on the mechanical properties of single-layer particleboards made from a mixture of wood particles $(70 \%)$ and rice husk particles $(30 \%)$. Urea formaldehyde (UF) and phenol formaldehyde (PF) resin types with three different resin levels $(8,10$, and $12 \%)$ were used. Their results showed a slight improvement in the MOE and MOR when the UF and $\mathrm{PF}$ resin increased from $8 \%$ to $10 \%$, however, there were significant improvements for the $12 \%$ resin content panels.

The mean values of water absorption and thickness swelling after 2 and 24 hours of water immersion for the produced panels are presented in (Table 2).

The mixtures improved the water absorption and thickness swelling after (2h. and 24h.) of water immersion for the panels with $9 \%$ UF resin content, except for the (E-C) panels. Moreover, both properties were improved when the resin content increased to $13 \%$. The mixtures for the 13\% UF resin content panels improved the water absorption and thickness swelling and even for the (E-C) panels. According to (Maloney, 1993), there are some factors that controls the water resistance of particleboards not only resin level or raw material density, such as different particle sizes, densities, pressing conditions (temperature, pressure, and press time, etc.)

The high values of water absorption and thickness swelling for the E-C panels with $9 \%$ (UF) resin content may be attributed to the extractive content of the mixture which lower the bonding between the particles and adhesive. In contrast, when increasing the resin content with $13 \%$ both properties in the (E-C) were improved, as the higher percentage of resin overcome this problem. To improve the characteristics of the $9 \%$ (E-C) panels in this study, pre-treatments to remove the extractives such as presoaking of particles in hot or cold water may be applied and this point needs to be investigated in further studies.

The reason for decreasing the thickness swelling with increasing resin content to the greater area of particles is covered with adhesive. When voids are filled with resin that also indicates that particles are more bonded together, consequently, less water can enter between particles ( Kelly, 1977; Schneider et al., 1996).

This study was in agreement with other studies on different wood species as raw materials. For example, Taş and Sevinçli (2015), reported that the values of thickness swelling after $24 \mathrm{~h}$ soaking in water of Pinus brutia were, 57.18, 47.16, and 36.14 for $6 \%, 10 \%$, and $12 \%$ resin content, respectively. 
Table 2. Mean values of water absorption and thickness swelling after $2 \mathrm{~h}$ and $24 \mathrm{~h}$ water immersion.

\begin{tabular}{|c|c|c|c|c|c|c|c|c|}
\hline \multirow[b]{4}{*}{ Items } & \multicolumn{4}{|c|}{ Water absorption } & \multicolumn{4}{|c|}{ Thickness swelling } \\
\hline & \multicolumn{4}{|c|}{ UF resin content (\%) } & \multicolumn{4}{|c|}{ UF resin content (\%) } \\
\hline & \multicolumn{2}{|c|}{$9 \%$} & \multicolumn{2}{|c|}{$13 \%$} & \multicolumn{2}{|c|}{$9 \%$} & \multicolumn{2}{|c|}{$13 \%$} \\
\hline & $2 \mathrm{~h}$ & $24 \mathrm{~h}$ & $2 \mathbf{h}$ & $24 \mathrm{~h}$ & $2 \mathrm{~h}$ & $24 h$ & $2 \mathrm{~h}$ & $24 h$ \\
\hline \multirow[t]{2}{*}{ C. cunninghamiana $(\mathrm{C})$} & $56.29^{c}$ & $67.23^{c}$ & $40.69^{b}$ & $52.61^{b}$ & $16.04^{\mathrm{cd}}$ & $24.17^{\text {cd }}$ & $13 . \varepsilon, b$ & $21.97^{\mathrm{b}}$ \\
\hline & $(2.53)$ & $(0.79)$ & $(0.94)$ & $(1.35)$ & $(0.69)$ & $(0.56)$ & $(0.28)$ & $(0.59)$ \\
\hline \multirow[t]{2}{*}{ E. camaldulinsis $(\mathrm{E})$} & $56.80^{c}$ & $68.01^{\mathrm{c}}$ & $42.25^{\mathrm{b}}$ & $52.95^{\mathrm{b}}$ & $16.68^{c}$ & $24.67^{c}$ & $13.54^{\mathrm{b}}$ & $21.63^{\mathrm{bc}}$ \\
\hline & $(0.34)$ & $(1.86)$ & $(2.02)$ & $(2.98)$ & $(0.68)$ & $(1.27)$ & $(0.50)$ & $(0.40)$ \\
\hline \multirow[t]{2}{*}{ P. halepensis $(\mathrm{P})$} & $78.42^{\mathrm{b}}$ & $88.36^{\mathrm{b}}$ & $63.80^{\mathrm{a}}$ & $74.08^{\mathrm{a}}$ & $18.65^{\mathrm{b}}$ & $26.80^{\mathrm{b}}$ & $14.46^{\mathrm{a}}$ & $24.55^{\mathrm{a}}$ \\
\hline & $(0.68)$ & $(1.12)$ & $(4.01)$ & $(1.99)$ & $(1.1)$ & $(0.17)$ & $(0.36)$ & $(0.69)$ \\
\hline \multirow[t]{2}{*}{ E-C } & $87.97^{\mathrm{a}}$ & $98.49^{\mathrm{a}}$ & $34.86^{\mathrm{d}}$ & $45.62^{\mathrm{d}}$ & $22.35^{\mathrm{a}}$ & $28.99^{\mathrm{a}}$ & $9.32^{\mathrm{d}}$ & $15.91^{\mathrm{d}}$ \\
\hline & $(2.74)$ & $(5.02)$ & $(1.08)$ & $(1.03)$ & $(0.42)$ & $(0.46)$ & $(0.32)$ & $(0.34)$ \\
\hline \multirow[t]{2}{*}{ E-P } & $54.81^{\mathrm{c}}$ & $62.07^{\mathrm{d}}$ & $37.62^{c}$ & $48.76^{\mathrm{c}}$ & $14.75^{\mathrm{d}}$ & $22.61^{\mathrm{d}}$ & $12.14^{\mathrm{c}}$ & $19.94^{\mathrm{c}}$ \\
\hline & $(2.24)$ & $(1.02)$ & $(0.97)$ & $(0.54)$ & $(0.52)$ & $(0.87)$ & $(0.14)$ & (1.64) \\
\hline \multirow[t]{2}{*}{ C-P } & $46.52^{\mathrm{d}}$ & $56.35^{\mathrm{e}}$ & $30.72^{\mathrm{e}}$ & $41.76^{\mathrm{e}}$ & $13.11^{\mathrm{e}}$ & $20.82^{\mathrm{e}}$ & $8.82^{\mathrm{d}}$ & $14.49^{\mathrm{d}}$ \\
\hline & $(2.50)$ & $(3.01)$ & $(1.29)$ & $(0.67)$ & $(0.31)$ & $(0.49)$ & $(0.35)$ & $(0.44)$ \\
\hline
\end{tabular}

* Values in percentage; Means in the same column which do not share a common letter are significantly different at $95 \%$ confidence level.

In this study, wax was not added to improve the water resistance of the panels. Therefore, the addition of paraffin wax will improve the physical properties. There are other additives that may improve the performance such as use of phenolic resins, coating of the particleboard surfaces and acetylating of particles can improve the water repellency of the panels (Rowell and Norimoto, 1988; Nemli et al., 2005; Guntekin et al., 2008 and Ayrilmis et al., 2009).

Based on the findings of this research, there is a need to expand in tree plantations establishment especially fast-growing trees irrigated with treated wastewater and this is important to provide continuous raw materials for manufacturing wood-based panels such as particleboard.

\section{CONCLUSIONS}

Single layer particleboards were manufactured using Eucalyptus camaldulensis (E), Pinus halepensis (P), and Casuarina cunninghamiana (C) wood particles from trees irrigated with treated wastewater and their mixtures among the three genera (E-C, E-P, and C-P) with two levels (9\% and 13\%) of urea formaldehyde (UF) adhesive. The result of this study showed that all particleboards produced with $9 \%$ and $13 \%$ UF glue level satisfied the minimum requirement indicated by the European standard for MOR except the (P) and (E-C) panels with $9 \%$ resin content. The mechanical properties of the $13 \%$ resin content panels were above the minimum requirement of the European standard (EN $312,2005)$ for general-purpose boards for use in dry conditions. Almost particleboards produced with $9 \%$
UF resin level does not satisfy the minimum requirement of the European standard for MOE. All particleboards produced with $13 \%$ and 9\% UF resin achieved the minimum values recommended by the European standard for IB. Based on the result of this study the $13 \%$ UF resin level panels had lower values of water absorption and thickness swelling than those observed in the $9 \%$ UF resin. panels. It was clear that the mixture improved the physical properties (water absorption and thickness swelling). The obtained data showed that the (E-C) with 9\% UF resin level panels had the highest values of water absorption and thickness swelling. The (C-P) panels had the best mechanical and physical properties compared with the other produced panels. The particleboards with low mechanical properties could be used for insulation purposes. The results showed the suitability of the three species and their mixtures which irrigated with treated wastewater as raw material for particleboard industry in Egypt.

\section{ACKNOWLEDGEMENTS}

Deep appreciation is expressed to Prof. Dr. Mohamed El-Rouby, professor of Agronomy, Faculty of Agriculture, Alexandria University, for his great advice and assistance through the phase of the statistical analysis. Also, our deep appreciation goes to Prof. Dr. Mohamed El-Raey, Institute of Graduate Studies and Research, Alexandria University for his valuable suggestion and comments. 


\section{REFERENCES}

Ashori A., and A. Nourbakhsh. 2008. Effect of press cycle time and resin content on physical and mechanical properties of particleboard panels made from the underutilized low-quality raw materials. Industrial crops and products, 28(2): 225-230.

ASTM D 1105-96 American Society for Testing Materials. 2000. Standard test method for preparation of extractivefree wood. ASTM International, West Conshocken, PA, pp. 147-148.

Ayrilmis N., J. H. Kwon, T. H. and Han. 2012. Effect of resin type and content on properties of composite particleboard made of a mixture of wood and rice husk. International Journal of Adhesion and Adhesives, 38: 79-83.

Ayrilmis N., U. Buyuksari, E. Avci, and E. Koc. 2009. Utilization of pine (Pinus pinea L.) cone in manufacture of wood based composite. Forest Ecology and Management, 259(1): 65-70.

Coppen J. J. (Ed.). 2003. Eucalyptus: the genus Eucalyptus. CRC Press.

Cortina J., B. Amat, V. Castillo, D. Fuentes, F. T. Maestre, F. M. Padilla, and L. Rojo. 2011. The restoration of vegetation cover in the semi-arid Iberian southeast. Journal of Arid Environments, 75(12), 1377-1384.

Dinwoodie J.M. 1978. The properties and performance of particleboard adhesives. J Inst Wood Sci;8:59-68.

Doughty R. W. 2000. The eucalyptus: a natural and commercial history of the gum tree. Baltimore, MD: The Johns Hopkins Univ. Press. 237 pp.

EN 310, European Standard. 1993. Wood based Panels /determination of modulus of elasticity in bending and of bending strength. CEN European Committee for Standardisation.

EN 312, European Standard. 2005. Particleboards specifications. European committee for standardization, brussels, belgium.

EN 319: European Standard. 1993. Particleboards and fibreboards/determination of tensile strength perpendicular to the plane of the board. CEN European Committee for Standardisation.

EN 317, European Standard. 1993. Particleboards and Fiberboards, Determination of Swelling in Thickness after Immersion. CEN European Committee for Standardisation.

FAO: Food and Agriculture Organization of the United Nations. (2020). FAOSTAT Database. Rome, Italy: FAO. Retrieved February 15, 2020 from http://www.fao.org/faostat/en/\#data/FO

Foster W. G. 1967. "Species variation," Proceedings of the W.S.U. particleboard symposium, Vol. 1, Washington, DC, USA.

Gindel I. 1944. Aleppo pine as a medium for tree ring analysis. Tree Ring Bull. 11: 6-8.
Guntekin E., and B. Karakus. 2008. Feasibility of using eggplant (Solanum melongena) stalks in the production of experimental particleboard. Industrial Crops and Products, 27(3): 354-358.

Hassan, K. T. S. 2009. Formaldehyde emission levels and particleboard characteristics of locally grown eucalypt biomass. MSc. Faculty of Agriculture, Alexandria University.

Hudson C. J., J. S. Freeman, A. A. Myburg, B. M. Potts, and R. E. Vaillancourt. 2015. Genomic patterns of species diversity and divergence in Eucalyptus. New Phytologist, 206(4): 1378-1390.

Kandeel S. A. E., J. G. Isebrands, and H. M. Aly. 1982. Windbreak-grown Casuarina and Eucalyptus trees for unbleached kraft pulp. Wood and Fiber Science, 14(4): 287-295.

Kelly, M. W. 1977. Critical literature review of relationships between processing parameters and physical properties of particleboard (Vol. 10). US Department of Agriculture, Forest Service, Forest Products Laboratory.

Maloney T.M. 1993. Modern particleboards \& dry-process fiberboard manufacturing. Forest Products Society, Madison, Wisconsin. 681p.

Nemli G., Y. Örs, and H. Kalaycığlu. 2005. The choosing of suitable decorative surface coating material types for interior end use applications of particleboard. Construction and building materials, 19(4): 307-312.

Pan Z., Y. Zheng, R. Zhang, and B. M. Jenkins. 2007. Physical properties of thin particleboard made from saline eucalyptus. Industrial Crops and Products, 26(2): 185-194.

Rowell R.M., and M. Norimoto. 1988. Dimensional stability of bamboo particleboards made from acetylated particles. Mokuzai Gakkaishi 34 (7): 627-629.

Saad M. J., and I. Kamal. 2012. Mechanical and physical properties of low density kenaf core particleboards bonded with different resins. Journal of Science and Technology, 4(1).

Schneider M. H., Y. H.Chui, and S. B. Ganev. 1996. Properties of particleboard made with a polyfurfurylalcohol/urea-formaldehyde adhesive. Forest products journal, 46(9): 79.

Taş H. H., and Y. Sevinçli. 2015. Properties of particleboard produced from red pine (Pinus brutia) chips and lavender stems. BioResources, 10(4): 7865-7876.

Xu J., R.Sugawara, R.Widyorini, G.Han , and S.Kawai. 2004. Manufacture and properties of low-density binderless particleboard from kenaf core. Journal of Wood Science, 50(1), 62-67.

Zheng Y., Z. Pan, R. Zhang, B. M. Jenkins, and S. Blunk. 2006. Properties of medium-density particleboard from saline Athel wood. Industrial Crops and Products, 23(3): 318-326. 


\section{الملخص العربي}

الخو اص الفيزيائية والميكانيكية للخثب الحُبيبي المصنع من بعض الأشجار الخثبية المروية بمياه الصرف الصحي المعالجة

خالا طه سليمان حسن، إبر اهيم السيد خير الله، أحمد عامر الستاوى، هبة محمود عبد الله

غراء يوريا فورمالدهيد قد أعطت الحد الأدنى الذي نصت عليه المواصفة القياسية الأوروبية لكل من معامل المرونة ومعامل الكسر وقوة الرابطة الداخلية باستثناء معامل المرونة لتلك الالواح المصنعة من أشجار الصنوبر والتي كانت قريبة جداً من القيمة الموصي بها. ومن الجدير

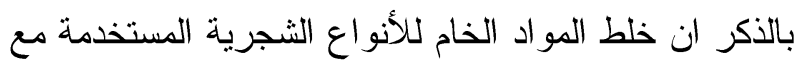
بعضها في صورة توليفات قد حسنت من الخواص الفيزيائية وهي مقاومة الألواح لامتصاص الماء و الانتفاخ في السمك مقارنة بالألواح الأخرى المنتجة من كل نوع على حدي وخاصة عند استخدام مستوى با \% من الغراء. وقد كانت الخواص الميكانيكية وخواص مقاومة الألواح للماء أقل ما يمكن في الألواح المنتجة من توليفات من الكافور و الكازوارينا معاً عند استخدام مستوى غراء 9 \% وقد أظهرت الأنواع الثجرية محل الدارسة صلاحيتها لإنتاج الواح الخشب الحبيبي وذللك باستخدام ظروف التصنيع المحددة في تلك الدارسة.
تهدف هذه الدارسة الى تصنيع ألواح الخشب الحبيبي من أثجار الكافور و الكازوارينا والصنوبر النامية في مصر و المروية بمياه الصرف الصحي من غابة الصداقة المصرية الصينية وهى احدى أهم الغابات الصناعية في جمهورية مصر العربية وفى هذه الدارسة نم تصنيع ألو اح من الأنواع

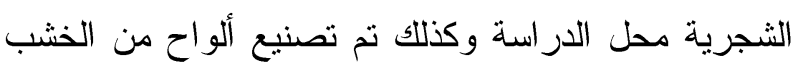
الحبيبي بتوليفات من تلك الأنواع وبعضها بنسبة . 0\% لكل مادة خام ونم استخدام مستويين من غراء اليوريا

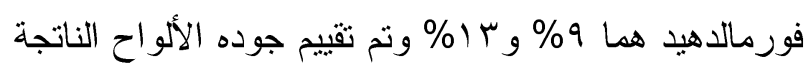
عن طريق اجر اء اختبار ات ميكانيكية على الالو اح المصنعة تمثلت في تقدير معامل المرونة ومعامل الكسر وقوة الرابطة الداخلية وكذلك تم اجراء اختبارات فيزيائية وهي وني

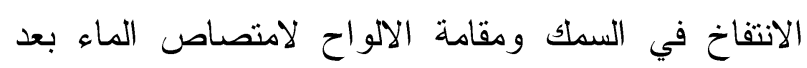

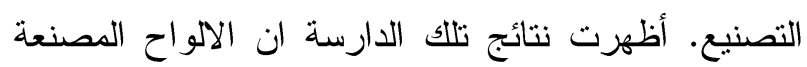
بتوليفات من الكازوارينا و الصنوبر معاً بمستوى غر اء 9 \% وسا \% أعطت أفضل خواص ميكانيكية وأعلى مقاومة لامتصاص الماء ومن النتائج المتحصل عليها في تللك الدراسة ان جميع الالو اح المصنعة باستخدام مستوي باه 